APS/SPR POSTER SESSION I

and Wine and Cheese Reception

Sponsored in part by grants from Roche and Wyeth Laboratories

Tuesday, May $1,1984,7$ PM

Continental Ballroom 1-9

1. COMMUNITY CORRELATES OF ADOLESCENT RISK-TAKING IN A SEMIRURAL COUNTY. Kathaleen C. Perkins (Spon. by Elizabeth R. McAnarney). Oswego, New York.

2. THE IMPACT OF SOCIAL STRESSORS AND SOCIAL NETWORKS ON PEDIATRIC MEDICAL CARE UTILIZATION. S.M. Horwitz, H. Morgenstern, L.F. Berkman, Yale Univ., New Haven.

3. ALTERATIONS IN REGIONAL BLOOD FLOW PRODUCED BY HIGH SALT DIET. A.P. Rocchini, K.P. Gallaher (Spon. A. Rosenthal) Univ. of Michigan, Ann Arbor. ('200)

4. HEMODYNAMIC EFFECTS OF INCREASING HEMOGLOBIN (HGB) CONCENTRATION IN CHILDREN WITH A RIGHT-TO-LEFT(R-L) VENTRICULAR SHUNT AND RELATIVE ANEMIA. Robert H. Beekman and Dwight $T$. Tuuri (Spon. by Maurice D. Kogut), Wright State Univ., Children's Med.Ctr., Dept. of Ped., Dayton. (140)

5. COMPARISON OF ISOLATED VENTRICULAR MYOCYTES FROM THREEWEEK OLD AND ADULT RABBITS. Rashid Nassar, Mary C. Reedy, and Page A.W. Anderson. Duke Univ. Med. Ctr., Durham. (193)

6. ATRIAL PACING TO ESTIMATE SINOATRIAL CONDUCTION TIME IN CHILDREN. Robert M. Campbell, Macdonald Dick II, Paul Hees, Univ. of Michigan, C.S. Mott Children's Hosp., Div. of Ped. Cardiol., Ann Arbor. (146)

7. DOPPLER FLOW INDICES IN THE CENTRAL AORTA OF NEONATES. Deborah M. Friedman, M.D., Fredrick Z. Bierman, M.D., Div. of Ped., Columbia-Presbyterian Med. Ctr., New York. (157)

8. CHILDREN'S CARDIOVASCULAR REACTIVITY-RACIAL DIFFERENCES IN CARDIAC INDEX AND SYSTEMIC RESISTANCE RESPONSES TO EXERCISE. Bruce S. Alpert, Darlene Moes, Robert DuRant (Spon. by Albert Pruitt), Med. Coll. of Georgia, Dept. of Ped., Augusta. (130)

9. AUTONOMIC INFLUENCES UPON ELECTROPHYSIOLOGIC PARAMETERS OF SINUS NODE FUNCTION IN IMMATURE PUPPIES: EFFECTS OF CHEMICAL SYMPATHECTOMY. Mark Cohen, Roy Jedeikin, Robert Lewis, Paul Gillette (Spon. by Jerome Liebman), The Lillie Frank Abercrombie Section of Cardiol., Dept. of Ped., Baylor Coll. of Med. and Texas Children's Hosp., Houston. (153)

10. NEONATAL CARDIOVASCULAR EFFECTS OF VERAPAMIL. Norman Gootman, Barbara J. Buckley, Nancy A. Kaplan, Peter G. Griswold, Barbara J. Peterson, Schneider Children's Hosp., Long Island Jewish-Hillside Med. Ctr., Dept. of Ped., New Hyde Park. (160) 
11. SUDDEN UNEXPECTED CARDIAC DEATH IN A DEFINED COMMUNITY, AGES 1-21. Daniel R. Neuspiel and Lewis H. Kuller (Spon. by William H. Neches), Univ. of Pittsburgh, Dept. of Epidem., Pittsburgh. (196)

12. CHARACTERISTICS OF DIGOXIN INTERACTION WITH QUINIDINE, VERAPAMIL AND AMIODARONE: IN VIVO AND IN VITRO STUDIES. Gideon Koren, Stuart MacLeod, Div. Clin. Pharmacol., Hosp. for Sick Children, Toronto. (351)

13. RETINAL AND TISSUE VITAMIN E KINETICS IN THE NEWBORN KITTEN FOLLOWING VITAMIN E ADMINISTRATION. R. Bhat and R.J. Braun, (Spon. by D. Vidyasagar), Dept. of Ped., Univ. of Illinois Hosp., Chicago. (323)

14. CHEMORECEPTOR MEDIATED RESPONSE OF VENTILATION TO CAFFEINE INFUSION IN LAMBS. Pierre W. Blanchard, Steven Hobbs, Aurore Côté, Patrice Foulon, Michel A. Bureau (Spon. by Jacob Aranda), McGill Univ.-Montreal Children's Hosp. Res. Inst., Montrea1. (325)

15. PROSTAGLANDINS (PG) AND MYOCARDIAL CONTRACTILE FUNCTION IN GROUP B STREPTOCOCCAL (STREP) SHOCK. K.J. Peevy, S.A. Chartrand, H.J. Wiseman, R.C. Boerth and R.D. Olson, Univ. of So. Alabama, Dept. of Ped. and Pharm., Mobile. (374)

16. EFFECT OF FETAL THYROIDECTOMY ON THE METABOLIC RESPONSE TO BIRTH IN LAMBS. D.H. Polk, J.F. Padbury, C.C. Callegari, J. Newnnam, A. Reviczky and A.H. Klein, Dept. of Ped., Harbor-UCLA Med. Ctr., UCLA Sch. of Med., Torrance. (470)

17. EFEECT OF HYPOTHYROIDISM (HP) AND HYPERTHYROIDISM (HT) ON 125 I-EPIDERMAL GROWTH FACTOR (EGF) SPECIFIC BINDING (S.B.) TO NEWBORN (NB) LUNG (L) AND BRAIN (B) PLASMA MEMBRANE (PM). F. Sadiq, S. Devaskar, V. Chechani, S. Harris and U. Devaskar (Spon. W.J. Keenan) Dept. of Ped., St. Louis Univ. Sch. of Med., St. Louis. (484)

18. CLONING OF cDNA ENCODING BOVINE 21-HYDROXYLASE. Bon-Chu Chung, Karla J. Matteson, John E. Morin, and Walter L. Miller, Dept. of Ped., Univ. of California, San Francisco.(422)

19. H-Y INTERMEDIATE PHENOTYPE: A POSSIBLE CAUSE OF TESTICULAR DYSGENESIS. Thomas A. Wilson and Stephen S. Wachtel (Spon. by John Partin), SUNY at Stony Brook and New York Hosp.Cornell Med. Ctr., Div. of Ped. Endocrin., Stony Brook and New York. (1273)

20. MECHANISM OF DECREASED INSULIN ACTION IN TYPE A FAMILIAL INSULIN RESISTANCE. W. Frederick Schwenk, Robert A. Rizza, Lawrence J. Mandarino, Alvin B. Hayles, Morey W. Haymond, Mayo Med. Sch., Mayo Clinic and Fndn., Dept. of Ped. and Med., Rochester. (488) 
21. CONJUNCTIVAL AND NASOPHARYNGEAL CULTURES: CORRELATION WITH MIDDLE EAR FLUID IN CHILDREN WITH ACUTE OTITIS MEDIA. J.R. Groothuis, S. Berman, J. Thompson and P.F. Wright, Dept. of Ped., Univ. of Colorado Sch. of Med., Denver.

22. PROTEIN METABOLISM OF PARENTERALLY FED NEONATES: COMBINED 13C AND 15N STUDIES. P. Pencharz, J. Beesley, U. Canagarayar, J. Van Aerde, J. Renner, P. Sauer, D. Wesson, P. Swyer, Dept. Ped. \& Surg., Res. Inst., The Hosp. for Sick Children, Toronto. (672)

23. THE RELATIONSHIP OF ROTAVIRUS TO ACQUIRED MONOSACCHARIDE INTOLERANCE (AMI) IN YOUNG INFANTS. Veda N. Nichols, J. Kennard Fraley, William J. Klish, Kim Evans, G.S. Gopalakrishna, E. O'Brian Smith, Herbert L. Dupont, and Buford L. Nichols. Baylor Coll. of Med., USDA/ARS Children's Nutrition Res. Ctr. and Section of Gastroenterol., Dept. of Ped., Houston. (665)

24. FAMILIAL APNEA AND GaStROESOPHAgEAL REFLUX. Dorothy H. Kelly, Aubrey J. Katz, Lucienne A. Cahen, Alex F. Flores, Daniel C. Shannon, Dept. of Ped., Harvard Med. Sch., Boston. (634)

25. SEQUESTRATION OF IRON AS FERRITIN IN MACROPHAGES IN SKELETAL MUSCLE OF VITAMIN E DEFICIENT RABBITS. Jen-Yih Chu, Pitsamai Kanjananggulpan, Albert Chou, Daphne deMello, and Coy Fitch, St. Louis Univ., Dept. of Ped., Path., and Int. Med., St. Louis. (582)

26. EFFECT OF RACE \& NORMAL MATERNAL DIET ON BREAST MILK VITAMIN D CONCENTRATIONS. Bonny Specker, Reginald C. Tsang, Bruce Hollis, John Searcy, and Ron Levine, Univ. of Cincinnati and Case Western Univ., Cleveland. (705)

27. GASTRIC MOTILITY AND GI BLOOD FLOW: EFFECTS OF HYPOXEMIA IN THE NEWBORN PIGLET. Joanne S. Szabo, Barbara S. Stonestreet, William Oh, Brown Univ., Women \& Infants Hosp., Dept. of Ped., Providence. (711)

28. GLYCOPROTEINS OF HUMAN JEJUNAL CELLS: LOCATION, MATURATIONAL CHANGES AND INDIVIDUAL VARIATION. Milton Westphal, Bradley A. Schulte and Samuel S. Spicer, Med. Univ. of South Carolina, Dept. of Ped. and Path., Charleston. (728)

29. INTERACTION OF VITAMIN D (VID) BETWEEN MOTHER AND FETUS AT TERM: EVIDENCE FOR RACIAL VARIATION. W. Pittard, B. Hollis, CWRU, Dept. of Ped. \& Nutr., Cleveland. (705)

30. FETAL AUDITORY RESPONSES. Jason C. Birnholz (Spon. by Carl Hunt) Rush Med. Co11., Dept. of Radio1., Rush-PresbyterianSt. Luke Med. Ctr., Chicago. (242)

31. BIOCHEMICAL EVIDENCE OF CARDIOMYOPATHY IN GUINEA PIGS EXPOSED IN UTERO TO ALCOHOL. John D. Tobin, Jr., George R. Noren, James E. Surdy, Nancy A. Staley. Univ. of Minnesota Med. Sch., Hennepin Co. Med. Ctr., and VA Med. Ctr., Dept. of Ped. and Path., Minneapolis. (303) 
32. INCREASED ACETAMINOPHEN GLUTATHIONE METABOLITE FORMATION IN CHILDREN - ROLE IN DECREASED CHILDHOOD ACETAMINOPHEN HEPATOTOXICITY. Wayne R. Snodgrass, David Nyman and Avinoam Rachmel (Spon. by Michael A. Linshaw), Dept. of Ped. and Pharm.-Toxico1., Univ. of Kansas Med. Ctr., Kansas City. (297)

33. THE IMPACT OF CME ON PHYSICIAN PERFORMANCE, KNOWLEDGE AND PATIENT CARE. Larrie W. Greenberg, Leslie S. Jewett (Spon. by Donald W. Delaney) George Washington Univ. Sch. of Med. Children's Hosp. Natl. Med. Ctr., Dept. of Child Hlth. and Devel., Washington. (806)

34. PRENATAL DIAGNOSIS OF A GIRL WITH MUSCULAR DYSTROPHY CAUSED BY DE NOVO $t(X ; 4)(p 21 ; q 35)$, Jacquelyn Roberson, Danie1 L. Van Dyke, Bernard Mandelbaum, and Lester Weiss, Henry Ford Hosp. and Wayne State Univ., Detroit. (774)

35. THE ROLE OF ATP IN LYSOSOMAL CYSTINE EFFLUX. M.L. Smith, R. Potashnik, A.A. Greene, A.J. Jonas and J.A. Schneider, Dept. of Ped., Univ. of California, San Diego, LaJolla. (783)

36. A TWO HOUR PHENYLALANINE (P) LOAD FOR CARRIER DETECTION OF PHENYLKETONURIA (PKU). Joan E. Bailey-Wilson, Miriam G. Blitzer, Grace Kissling, Emmanuel Shapira, Tulane Univ. Sch. of Med., The Hayward Genet. Ctr., and Louisiana State Univ. Sch. of Med., Dept. of Biometry, New Orleans. (741)

37. SPONTANEOUS REVERSION AT THE HPRT LOCUS IN CELLS FROM A PATIENT WITH A MILD VARIANT OF THE LESCH-NYHAN SYNDROME. Arthur S. Aylsworth, Laird G. Jackson, Nicholas M. Kredich, Univ. of North Carolina Dept. of Ped., and the Biolog. Sci. Res. Ctr., Chape1 Hill; Jefferson Med. Coll. Div. of Genet., Philadelphia; Duke Univ. Dept. of Med. and the Howard Hughes Med. Inst., Durham. (740)

38. ACUTE CHEST SYNDROME (ACS) IN SICKLE CELL PATIENTS IS OFTEN DUE TO MYCOPLASMA PNEUMONIAE. Mortimer Poncz, Ellen Kane, and Frances M. Gill (Spon. by Elias Schwartz), Univ. of Pennsylvania Sch. of Med, and The Children's Hosp. of Philadelphia, Dept. of Ped., Philadelphia. (905)

39. VITAMIN B-12 ( $\mathrm{Cb}$ ) AND FOLATE INTERRALATIONSHIP IN A CASE OF HOMOCYSTINURIA-METHYLMALONIC ACID (HC-MMA)-URIA DUE TO GENETIC CO-FACTOR DEFICIENCY. Yaddanapudi Ravindranath, Ingeborg Krieger, Children's Hosp. of Michigan, Detroit. (910)

40. PROTEIN C LEVELS DURING THE FIRST MONTH OF LIFE. Margaret Karpatkin, Pier Mannuccio Mannucci, Madhu Bhogal, Silvana Viganó, Michael Nardi, New York Univ. Med. Ctr., Dept. of Ped., New York and Hemophilia and Thrombosis Ctr., A. Bianchi Bonomi, Univ. of Milan, Italy. (882)

41. CHILDHOOD MONOSOMY 7 SYNDROME: A FAMILIAL DISORDER? William L. Carrol1, Michael D. Amylon, Michael P. Link, Karen Backer and Bertil E. Glader, Stanford Univ. Sch. of Med., Children's Hosp. at Stanford, Dept. of Ped., Div. of Hem./Onc., Stanford. ( 848 ) 
42. CT SCANING OF LIVER IRON DENSITY IN THALASSEMIA MAJOR: VALUABLE PREDICTOR OF CARDIAC DYSFUNCTION. NanCy F. OIivieri, A. Daneman, Melvin H. Freedman, Univ, of Toronto, Hosp. for Sick Children, Div. of Hem. \& Radiol., Toronto. (903)

43. TOWARD THE ELIMINATION OF VARICELLA IN CHILDREN WITH LEUKEMIA. Jean Taylor-Wiedeman, Philip A. Brune11, Clementina Geiser, and Ziad M. Shehab, U.T. HIth. Sci. Ctr., Dept. of Ped., San Antonio. (926)

44. THE EFFECT OF NIGHTLY SUBCUTANEOUS DESFERAL ON GROWTH AND SEXUAL MATURATION IN CHILDREN WITH THALASSEMIA MAJOR: NanCy F. Olivieri, F. John Holland, Melvin H. Freedman, Univ. of Toronto, Hosp. for Sick Children, Div. of Hem. \& Endocrin., Toronto. (902)

45. GOOD RESPONSE TO INTRAVENOUS GAMMAGLOBULIN OF PATIENTS WITH STEROID RESISTANT ACUTE ITP. James B. Bussel and Margaret W. Hilgartner, NYH-CUMC Div. Ped. Hem/Onco., New York. (847)

46. DANAZOL-INDUCED FACTOR IX AND VIII BYPASSING ACTIVITY. James J. Corrigan, Jr., Harinder S. Garewal, Brian G. M. Durie, Monette Jeter, Mary Lou Damiano, Dept. of Ped. and Int. Med., Univ. of Arizona Hlth. Sci. Ctr., Tucson. (856)

47. THE ROLE OF INTERLEUKIN 2 IN THE NEONATE. KarI Welte, James B. Bussel, Margaret W. Hilgartner, and Roland Mertelsmann, NY Hosp.-Cornell Med. Ctr., New York, Dept. of Ped., and Memorial Sloan-Kettering Div. of Hematopoiesis. (1027)

48. DEFECTIVE IMMUNOREGULATORY FUNCTIONS OF LYMPHOCYTES FROM PATIENTS WITH THE CHEDIAK-HIGASHI SYNDROME. Madhavan P.N. Nair, Stanley A. Schwartz, and Laurence A. Boxer, Univ. of Michigan, Dept. of Ped., Ann Arbor. (986)

49. PNEUMOCOCCAL TYPE 3 ANTIBODY IS RESTRICTED TO THE $1 \mathrm{gG} 2$ SUBCLASS. Douglas J. Barrett and Elia M. Ayoub, Dept. of Ped., Univ. of Florida Coll. of Med., Gainesville. (941)

50. PROSTAGLANDIN SYNTHESIS BY RABBIT ALVEOLAR MACROPHAGES MEDIATED BY THE ALTERNATIVE COMPLEMENT PATHWAY ACTIVATION. Carlos M. Arroyave, Wei Hsueh, and Ruth L. Jordan, Northwestern Univ., Children's Mem. Hosp., Dept. of Ped. and Path., Chicago. (939)

51. DETECTION OF DONOR'S LYMPHOCYTES IN THE PERIPHERAL BLOOD OF NEONATES FOLLOWING EXCHANGE-TRANSFUSION. M. Xanthou, H. Mandyla, M. Benetou and C. Metaxotou, Med. Sch. of Athens "Univ. "Aghia Sophia" Children's Hosp. lst Dept. of Ped.Neonat. ICU. (1032) 
52. INTERACTION OF CHLAMYDIA TRACHOMATIS ( $C t$ ) AND POLYMORPHONUCLEAR LEUKOCYTES (PMNS): A POSSIBLE ROLE IN VIRULENCE. M.R. Hammerschlag, K. Suntharalingam, A. Gleyzer, S. Fikrig, SUNY-Downstate Med. Sch., Dept. of Ped., Brooklyn. (1086)

53. THE POTENTIAL FOR ORAL ANTIBIOTIC THERAPY FOR PSEUDOMONAS INFECTIONS IN CHILDREN. Melvin I. Marks, Stephen A. Chartrand, and Ronald Scribner, Univ. of Oklahoma Hith. Sci. Ctr. and Univ. of So. Alabama, Dept. of Ped., Oklahoma City and Mobile. (1110)

54. PLACEBO-CONTROLLED TRIAL OF LIVE ATTENUATED COLD-ADAPTED (CA) INFLUENZA A VACCINES (H1N1 \& H3N2) VERSUS INACTIVATED WHOLE VIRUS INFLUENZA A (H3N2) VACCINE. Sandor Feldman, Peter Wright, Jo Mahoney, Juliette Thompson and Paula Robertson, Dept. of Ped., St. Jude Children's Res. Hosp., Memphis, Vanderbilt Univ., Nashville. (1071)

55. ROLE OF GAMMA-GLUTAMYL TRANSPEPTIDASE (GGT) IN AMINO ACID TRANSPORT. J.W. Foreman, B. Hsu, S. Corcoran, K. Ginkinger, S. Segal, Univ. of Pennsylvania Sch. of Med., Children's Hosp. Dept. of Ped., Philadelphia. (1185)

56. LEAD TOXICITY: INTERACTIONS BETWEEN LEAD (Pb), ZINC ( $\mathrm{Zn}$ ) AND CALCIUM ( $\mathrm{Ca}$ ) IN BONE ORGAN CULTURE. John F. Rosen, Albert Einstein Coll. of Med., Montefiore Med. Ctr., Dept. of Ped., Bronx. (1219)

57. CONGENITAL MALFORMATIONS AND EXPOSURE TO EXOGENOUS FEMALE SEX HORMONES. Edward J. Lammer, Jose F. Cordero, Godfrey P. Oakley, Jr., Ctr. for Environmental Hlth., Public Hlth. Serv., US Dept. of HIth, and Human Services, Atlanta. (1264)

58. NORMALIZING FUNCTIONAL RESIDUAL CAPACITY (FRC) IN RDS. P. Richardson, C. Bose, F. Gonzalez, G. King, N. Shaw, and J. Carlstrom, (Spon. by H. Hill), Dept. of Ped., Univ. of Utah Med. Ctr., Salt Lake City. (1482)

59. CLASSROOM PERFORMANCE, HEALTH, SOCIAL FACTORS OF VERY LOW BIRTH WEIGHT (VLBW) CHILDREN: FOLLOW-UP AT 5-8 YEARS. Betty L. Eilers, Melissa A. Wilson, Diane M. Gagel, Nirmala S. Desai, M. Douglas Cunningham, Col. of Med., Univ. of Kentucky, Dept. of Ped., Lexington. (1346)

60. BONE MARROW EXAMINATIONS IN SEPTIC NEUTROPENIC NEONATES. J.G. Wheeler, J.S. Abramson, R.J. Boyle, A.R. Chauvenet, C.A. Johnson, S.M. Block, R.J. Dillard, Bowman Gray Sch. of Med., Winston-Salem (1556)

61. PULMONARY VASCULAR EFFECTS OF POSTOPERATIVE ANESTHESIA IN CONGENITAL DIAPHRAGMATIC HERNIA. John D. Murphy, Robert K. Crone, Joseph P. Vacanti (Spon. by Thomas J. Hougen), Harvard Med. Sch., Children's Hosp., Dept. of Cardiol., Anest., and Surg., Boston. (1444) 
62. HIGH FREQUENCY OSCILLATION (HFO) VS. CONVENTIONAL MECHANICAL VENTILATION (CMV): BAROTRAUMA, SURFACTANT POOLS AND SURFACE TENSIONS IN PREMATURE LAMBS. Alfonso J. Solimano, A. Charles Bryan, Alan H. Jobe, Machiko Ikegami, Harris Jacobs, UCLA Sch. of Med., Harbor-UCLA Med. Ctr., Dept. of Ped., Torrnace, and Hosp. for Sick Chidlren, Dept. of Ped., Toronto. (1512)

63. AN EXPERIMENTAL PRETERM MODEL OF EXTRAUTERINE DEVELOPMENT. Vinod K. Bhutani, Marla R. Wolfson, Nghia N. Tran, S. David Rubenstein \& Thomas H. Shaffer (Spon. by William W. Fox), Temple Univ. Sch. of Med., Dept. of Physiol. \& Ped., Univ. of Pennsylvania Sch. of Med., Pennsylvania Hosp., Dept. of Ped., Philadelphia. (1300)

64. THE ADVERSE EFFECT OF SUPRAVENTRICULAR TACHYCARDIA ON CARDIAC OUTPUT IN THE NEONATE. D. Alverson, W. Berman, Jr., T. Dillon, L. Papile, H. Koffler, J. Johnson, Univ. of New Mexico, Dept. of Ped., Albuquerque. (1278)

65. WHOLE BLOOD VISCOSITY DETERMINED BY PLASMA PROTEIN, HEMATO CRIT, AND MEAN CORPUSCULAR VOLUME. O. Linderkamp, D.W. Roloff (Spon. by W.F. Howatt), Dept. of Ped., Univ.of Munich, West Germany. (1486)

66. INDOMETHACIN THERAPY ON THE FIRST DAY OF LIFE IN VERY-LOWBIRTH-WEIGHT INFANTS. Lynn Mahony, Randall Caldwell, Donald Girod, Roger Hurwitz, Robert Jansen, James Lemons, Richard Schreiner, Dept. of Ped., Indiana Univ., Indianapolis. (1424)

67. METABOLISM OF VERY LOW DENSITY LIPOPROTEIN (VLDL) BY HUMAN PLACENTA IN VITRO. Dennis Black, Kerry King and Peter Whitington, Dept. of Ped., Univ. of Tennessee Ctr. for the Hlth. Sci. and LeBonheur Children's Med. Ctr., Memphis. (1555)

68. HIGH FREQUENCY VENTILATION IN THE MANAGEMENT OF HYLINE MEMBRANE DISEASE. R. Bell, T. Kueh1, M. Escobe, D. Null, J. Coalson, N. Ackerman, R. delemos (Spon. by Robert Kotas) Dept. of Ped. and Path., Wilford Hall USAF Med. Ctr., Univ. of Texas HIth. Sci. Ctr., Southwest Fndn. for Res. \& Educ., San Antonio. (1295)

69. THE EFFECT OF INTRAVENTRICULAR HEMORRHAGE (IVH) ON REGIONAL CEREBRAL BLOOD FLOW ( $r$ CBF) IN NEWBORN DOGS. Daniel G. Batton, Elizabeth E. Nardis, Jonathan Hellmann (Spon. by M. Jeffrey Maisels), Pennsylvania State Univ. Coll. of Med., M.S. Hershey Med. Ctr., Dept. of Ped., Hershey. (1287)

70. TUBULAR DYSFUNCTION IN INFANTS WITH MECONIUM STAINED AMNIOTIC FLUID - DIAGNOSIS USING B2 MICROGLOBULIN. Ronald J. Portman, Jennifer W. Cole, Jeffrey M. Perlman, Yin Lim, Alan M. Robson, Washington Univ. Sch. of Med., St. Louis Children's Hosp., Dept. of Ped., St. Louis. (1469) 
71. HYPEROSMOLALITY (HO) AUGMENTED REGIONAL BRAIN BILIRUBIN DEPOSITION (RBBD) IN NEWBORN PIGLETS (P). G.H. Burgess, B.S. Stonestreet, W.J. Cashore, W. Oh, Brown Univ. Women \& Infants Hosp., Dept. of Ped., Providence. (1311)

72. THE EFFECT OF TIN-PROTOPORPHYRIN ON BILIRUBIN PRODUCTION IN NEWBORN RATS AFTER HEMATOMA FORMATION. Andrew M. Posselt, Clark G. Ochikubo, Hendrik J. Vreman, and David K. Stevenson, Dept. of Ped., Stanford Univ. Sch. of Med., Stanford. (1524)

73. CONCENTRATION AND FLOW RELATIONSHIPS FOR ENTRY OF UNBOUND BILIRUBIN (BR) IN RAT BRAIN. William J. Cashore and Michael Silberberg, Brown Univ., Women \& Infants Hosp., Dept. of Ped., Providence. (1312)

74. EFFECT OF ENERGY INTAKE AND ENERGY EXPENDITURE ON RECOVERY OF RESPIRATORY ${ }^{3} \mathrm{CO}_{2}$ IN NEONATES. J. Van Aerde, P. Sauer, U. Canagarayar, J. Beesley, J. Renner, D. Wesson, P. Swyer, P. Pencharz, Dept. of Ped. \& Surg., Univ. of Toronto, Res. Inst., The Hosp. for Sick Children, Toronto. (1214)

75. PROPHYLACTIC INDOMETHACIN AND INTRAVENTRICULAR HEMORRHAGE (IVH) IN THE PREMATURE, E.S. Setzer, B.M. Morse, R.N. Goldberg, M. Smith, and E. Bancalari, Univ. of Miami, Jackson Mem. Hosp., Dept. of Ped. and Radio., Miami. (1498)

76. AUDITORY NERVE AND BRAINSTEM RESPONSES IN NEWBORN INFANTS WITH HYPERBILIRUBINEMIA. Hajime Nakamura, Satoshi Takada, Roberto Shimabuku and Hirokuni Negishi (Spon. by Audrey K. Brown), Kobe Univ. Sch. of Med., Takatsuki Gen. Hosp. Dept. of Ped., Kobe, Japan. (1445)

77. EFFECT OF A SINGLE BREATH OF 100\% OXYGEN ON RESPIRATION IN NEONATES DURING SLEEP. Tazeem Aizad, Jaya Bodani, Don Cates, Leanne Horvath and Henrique Rigatto, Dept. of Ped., Univ. of Manitoba, Winnipeg. (1483)

78. RED BLOOD CELL (RBC) MEMBRANE DEFORMABILITY AND WHOLE BLOOD VISCOSITY IN INFANTS OF DIABETIC MOTHERS (IDM). Arun K. Pramanik and Narla Mohandas (Spon. by J. Wilson), Dept. of Ped., LSU Med. Ctr., Shreveport, and Lab. Med., Univ. of Calif., San Francisco. (1470)

79. CHANGES IN EPINEPHRINE (E) AND MEAN ARTERIAL BLOOD PRESSURE (MABP) DURING HYPERCARBIA (HC): EFFECTS ON BRAIN BLOOD FLOW (BBF) IN THE NEWBORN PIGLET. Ann-Mari Brubakk, Dag Bratlid, William Oh, and Barbara S. Stonestreet, Brown Univ. Women \& Infants Hosp., Dept. of Ped., Providence. (1449)

80. EFFECTS OF $\mathrm{NaHCO}_{3}$ ON CEREBRAL BLOOD FLOW (CBF) DURING HYPOXIA AND ACIDOSIS IN NEWBORN PIGLETS. Abbot R. Laptook (Spon. by C.R. Rosenfeld), Southwestern Med. Sch., Dept. of Ped., Da11as. (1415) 
81. RIFAMPIN AND PENICILLIN THERAPY FOR ELIMINATING NASAL COLONIZATION OF TYPE III GROUP B STREPTOCOCCI (GBS) IN INFANT RATS. D. Delaplane Millard, Stanford T. Shulman, Ram Yogev, Northwestern Univ. Med. Sch., Children's Mem. Hosp., Dept. of Ped., Chicago. (1438)

82. SELECTIVE ELEVATION OF SYSTEMIC BLOOD PRESSURE IN AN ANIMAL MODEL OF PULMONARY HYPERTENSION: AN ALTERNATIVE STRATEGY FOR PPHN. William L. Meadow and Brian F. Rudinsky (Spon. by K.S. Lee), Univ. of Chicago Med. Ctr., Dept. of Ped., Chicago. (1434)

83. CORD BLOOD COAGULATION CHANGES IN MATERNAL HYPERTENSION. Charles D. Lox, R. Ann Word, Monette Jeter and James J. Corrigan, Jr., Dept. of OB-GYN, Texas Tech. Univ. H1th. Sci. Ctr., Lubbock, and Dept. of Ped., Univ. of Arizona H1th. Sci. Ctr., Tucson. (1327)

84. PH, NOT PCO2, DECREASES HYPOXIC PULMONARY VASOCONSTRICTION (HPV) IN THE NEWBORN LAMB. Michael D. Schreiber, Michael A. Heymann, and Scott J. Soifer, Univ. of Calif., Cardiovasc. Res. Inst. and Dept. of Ped., San Francisco. (1510)

85. DEVELOPMENT OF MECHANICAL STABILITY OF THE RESPIRATORY SYSTEM IN PRETERM INFANTS. Gregory P. Heldt (Spon. by Richard D. Bland), Univ. of Calif., and Cardiovasc. Res. Inst., San Francisco. (1394)

86. C-REACTIVE PROTEIN (CRP) AND $\boldsymbol{\alpha}_{1}$-ACID GLYCOPORTEIN (AGP) IN THE DIAGNOSIS OF NEONATAL NECROTIZING ENTEROCOLITIS (NEC). Alistair G.S. Philip, Léon Sann and Françoise Bienvenu, Dept. of Ped., Maine Med. Ctr., Portland, and Hôpital Debrousse, Lyon, France. (1466)

87. DELAYED FEEDINGS FAILS TO PREVENT NECROTIZING ENTEROCOLITIS IN VERY LOW BIRTH WEIGHT NEONATES. H. Birenbaim, S.G. Ostertag, E.F. La Gamma, (Spon. by P.A.M. Auld), Perinatology Ctr., N.Y,H-Cornell Med. Ctr., New York. (1414)

88. INTRAUTERINE DISTRESS IMPAIRS LACTOSE ABSORPTION IN THE FULL TERM INFANT. Stuart Berezin, Anita Bhole, Leonard J. Newman (Spon. by L. Shapiro), New York Med. Coll., Westchester Co. Med. Ctr., Dept. of Ped., Valhalla. (1296)

89. HYPEROXIA INDUCED PULMONARY VASCULAR AND LUNG ABNORMALITIES IN YOUNG RATS AND POTENTIAL FOR RECOVERY. Wendy Wilson, Michelle Mullen, Peter M. Olley, Marlene Rabinovitch, Univ. of Toronto, The Hosp. for Sick Children Dept. of Cardiol., Toronto. (1473)

90. SURVIVAL OF CYTOMEGALOVIRUS (CMV) ON ENVIRONMENTAL SURFACES. R.G. Faix (Spon. by G. Wilson), Dept. of Ped., Univ. of Michigan, Ann Arbor. (1351) 
91. EFFECTS OF SEVERE HYPOXIA ON DILATOR PROSTAGLANDIN SYNTHESIS. John Lieske, Cathy Hammerman and Elene Strates (Spon. by K.S. Lee), Univ. of Chicago, Dept. of Ped., Chicago. (1376)

92. FATAL EARLY-ONSET GROUP B STREPTOCOCCAL INFECTION WITH A NORMAL CBC. Robert D. Christensen, Gerald Rothstein, Harry R. Hill and Robert T. Hall, Univ. of Utah and Children's Mercy Hosp., Kansas City. (1313)

93. HYPERTENSION REDEFINED FOR CRITICALLY ILL NEONATES. E.K. Stork, W.A. Carlo, R.M. Kliegman, A.A. Fanaroff, CWRU, Rainbow Babies \& Child. Hosp., Dept. of Ped., Cleveland.(1352)

94. EFFECT OF PRENATAL GLUCOCORTICOID ON FETAL RAT LUNG PROSTAGLANDIN SYNTHESIS. Michael Y. Tsai, Mark W. Josephson, Bill Handschin, David M. Brown, Dept. of Lab. Med. and Path., Univ. of Minnesota, Minneapolis. (1536)

95. THE PRENATAL DEVELOPMENT OF NEONATAL MOTOR RHYTHMS. S. Robertson (Spon. by J. Kenne11), Dept. of Ped., Case Western Reserve Univ., Cleveland. (1485)

96. URINARY AND RENAL HISTOLOGICAL CHANGES IN CHILDREN WITH ACQUIRED IMMUNODEFICIENCY SYNDROME (AIDS). Jose Strauss, Brenda Montane, Gwendolyn Scott, Michael Freundich, Carolyn Abitbol, Gaston Zilleruelo, Victoriano Pardo, Dept. of Ped. and Path., Univ. of Miami, Miami. (1653)

97. ATRIOPEPTINS: NATRIURESIS OCCURS INDEPENDENT OF VASCULAR EFFECTS. Barbara R. Cole, John G. Boylan, Mary A. Kuhnline, Mark G. Currie, David M. Geller, and Philip Needleman, Wash. Univ. Med. Sch., Dept. of Ped. and Pharmacol., St. Louis.(1581)

98. RENAL TUBULAR REABSORPTION OF PHOSPHATE (Pi) DURING DEVELOPMENT. Frederick J. Kaskel, Adarsh M. Kumar, Leonard Feld and Adrian Spitzer, Albert Einstein Col1. of Med., Dept. of Ped., Bronx. (1647)

99. ULTRASTRUCTURAL EFFECTS OF L-CARNITINE, OCTANOYLCARNITINE AND OCTANOATE ON CHOROID PLEXUS. Chung S. Kim, Dall R. Dorgan and Charles R. Roe, Biol. Sci. Res. Ctr., Neurol., Dent. Res. Ctr., Univ. of NC, Chapel Hill and Dept. of Ped., Duke Med. Ctr., Durham. (1692)

100. ADRENOLEUKODYSTROPHY (ALD)WITH TRANSIENT AMAUROSIS WITHOUT CLINICAL DEGENERATION, A DISEASE VARIANT OR THIRD ALLELE. Gary G. Carpenter, Leonard J. Graziani, Jefferson Med. Coll. Philadelphia; Hugo W. Moser, John F. Kennedy Inst., Baltimore; Herbert H. Schaumberg, Albert Einstein Coll. of Med., New York (Spon. by Herbert C. Mansmann, Jr., ) (1669) 
101. CORTICAL DEPENDENCE OF MID AND LATE EVOKED RESPONSES IN HUMAN BRAIN: HYDRANENCEPHALLY. Ira T. Lott, David McPherson, Arnold Starr and Dvora Cyrlak, Dept. of Ped. and Neurol., Univ. of California Irvine Med. Sch. (1698)

102. CAROTID BODIES MEDIATE THE ATTENUATING EFFECT OF BETAADRENERGIC AGONISTS ON APNEA REFLEX RESPONSE TO LARYNGEAL WATER ADMINISTRATION IN NEWBORN LAMBS. Jens Grogaard, Annick Van den Abbeele, Elizabeth Krueger, and Hakan Sundell, Vanderbilt Univ. Sch. of Med., Dept. of Ped., Nashville. (1869)

103. AROUSAL (AR), APNEA AND SIGHING FOLLOWING LARYNGEAL STIMULATION (LS) IN SLEEPING TERM NEWBORN LAMBS. F. Marchal, J.P. Crance, P. Vert, Dept. of Physiol. and Neonat., Univ. of Nancy, France. (1805)

104. POOR VENTILATORY RESPONSE TO CO 2 IN INFANTS WITH BRONCHOPULMONARY DYSPlasia (BPD). T.F. Yeh, H. Pate 1, R. Jain, A. Mora, R.S. Pildes, Cook Co. Hosp., Univ. of Illinois, Dept. of Ped., Chicago. (1829)

105. PROSPECTIVE ANALYSIS OF HEART RATE AND BREATHING PATTERNS IN INFANTS SUCCUMBING TO SIDS AND IN CONTROLS. David Gordon, David G. Southa11, Dorothy H. Kelly, Adrian Wilson, Solange Akselrod, Jean Richards, Barney Kenet, Robert Kenet, David Carley, Richard J. Cohen and Daniel C. Shannon, Ped. Pulm. Unit, Children's Service, MGH, Boston. (1849)

106. A 22 YEAR STUDY OF CHILDHOOD RESISTANT TUBERCULOSIS WITH EMPHASIS ON THE SUSCEPTIBILITY PATTERN OF MATCHED PATIENT AND SOURCE CASE STRAINS. Phillip Steiner, Milicent Mitchell, and Madu Rao (Spon. by Laurence Finberg), State Univ. of New York, Downstate Med. Ctr., Brooklyn. (1863)

107. ALTERATION OF THEOPHYLLINE PHARMAKOKINETICS DUE TO R.S.V. INFECTION. M. Rao, M. Ames, M. Mitchell and P. Steiner (Spon. by L. Finberg), Downstate Med. Ctr., SUNY, Dept. of Ped., Brooklyn. (1833)

108. SURFACE ACTIVE MATERIAL (SAM) AND COMPLIANCE CHANGE DURING RECOVERY FROM EXPERIMENTAL HYALINE MEMBRANE DISEASE (HMD). J.C. Jackson, S. Palmer, T.A. Standaert, J. Murphy, W.E. Truog, D.E. Woodrum, R.J. Badura, G.K. Sorensen, J.F. Watchko, W.A. Hodson, Dept. of Ped., Univ. of Washington, Seattle. (1787)

109. INFLUENCE OF BREATHING PATTERN, SLEEP STATES, AND MATURATION ON FUNCTIONAL RESIDUAL CAPACITY (FRC) IN NEWBORN INFANTS. H. Walti, M.F. Radvanyi, M. Chaussain, G. Moriette, J.P. Relier (Spon. by A. Minkowski), INSERM U.29, Hôpital Port Roya1, Paris, France. (1877) 
110. CONTROLLED TRIAL OF A PROTEIN-FREE SYNTHETIC SURFACTANT IN PRETERM RABBITS. Neil M. Derechin, Mureen A. Schlueter, Cynthia L. Brown, William H. Tooley, John A. Clements, and Richard D. Bland, Cardiovasc. Res. Inst., Dept. of Ped., Univ. of Calif., San Francisco. (1744)

111. THE EFFECT OF SLEEP STATE AND CO INHALATION ON THE CONTROL OF EXPIRATORY DURATION IN THE NEWBORN INFANT. Patrick Van Reempts, Guy Meriette, Dan Cates, Kathy Yorke, and Henrique Rigatto, Dept. of Ped., Univ. of Manitoba, Winnipeg. (1839)

112. THE EFFECT OF PERIODIC BREATHING AND SLEEP STATE ON THE INCIDENCE AND "STRUCTURE" OF AUGMENTED BREATHS IN NEONATES. Jaya Bodani, Tazeem Aizad, Kathy Yorke, and Henrique Rigatto, Dept. of Ped., Univ. of Manitoba, Canada. (1838)

113. ALKALOSIS ATTENUATES HYPOXIC PULMONARY VASOCONSTRICTION IN NEONATAL LAMBS. R.K. Lyrene, K.A. Welch, A. Dew, J.B. Phillips, Dept. of Ped., Univ. of Alabama, Birmingham. (1802)

114. DUPLICATION OF THE CHEST LAG IN REM SLEEP BY INSPIRATORY FLOW-RESISTIVE LOADING IN NREM SLEEP. Shahnaz Duara and Kimberley K. Bessard (Spon. by Allen Schwartz) Univ. of Maryland Sch. of Med., Univ. Of Maryland Hosp., Dept. of Ped., Baltimore. (1763)

115. ARE SURFACTANT PHOSPHOLIPID SYNTHESIS AND SECRETION LINKED IN THE FETAL TYPE II CELL? Martin Post, Arpy Barsoumian and Barry T. Smith, Harvard Med. Sch., Dept. of Ped., Bos.ton. (1830)

116. THE CELLULAR SITE OF INSULIN INHIBITION OF GLUCOCORTICOIDINDUCED LUNG MATURATION. Kathleen S. Carlson, Martin Post and Barry T. Smith, Harvard Med. Sch., Dept. of Ped., Boston, (1752)

117. PERIPHERAL CHEMORECEPTOR DENERVATION AFFECTS FETAL BREATHING MOVEMENTS (FBM) IN SHEEP. D.T. Murai, C.H. Lee, J.A. Kitterman, L.D. Wallen, Univ. of Texas Hith. Sci. Ctr., San Antonio \& Univ. of Calif. San Francisco, Cardiovasc. Res. Inst. \& Dept. of Ped., San Antonio and San Francisco.(1824)

118. MEMBRANE POTENTIAL RESPONSES OF TYPE II CELLS DURING SURFACTANT SECRETION. Jacob N. Finkelstein, Richard L. Gallo, Robert H. Notter and Donald L. Shapiro, Univ. of Rochester Sch. of Med., Dept. of Ped. (Neonat.), Rochester, NY (1769)

119. TYPE II PNEUMOCYTE MEMBRANE PHOSPHOLIPID METHYLATION IS NECESSARY FOR SURFACTANT SECRETION. Karen D. HendricksMunoz and Donald L. Shapiro, Univ. of Rochester Sch. of Med., Strong Mem. Hosp., Dept. of Ped., Rochester. (1850)

120. AN INVESTIGATION OF THE MECHANISMS BY WHICH HYPERVENTILATION DECREASES PULMONARY VASCULAR RESISTANCE IN THE NEWBORN LAMB. Frederick C. Morin (Spon. by Donald L. Shapiro), Univ. of Rochester Sch. of Med., Strong Mem. Hosp., Dept. of Ped., Rochester. (1820) 
Wednesday, May 2, 1984, 7:30 AM

West Lounge/Garden Lane/ Embarcadero

1. USEFULNESS OF URINARY 6/3-HYDROXYCORTISOL (6 6 OHF) EXCRETION IN THE DIAGNOSIS OF CUSHING'S SYNDROME. P. Saenger, R.E. Peterson, Dept. of Ped., Montefiore Med. Ctr., Dept. of Med., Corne11 Univ. Med. Col1., New York. (21)

2. SCREENING ADOLESCENT MALES FOR SEXUALLY TRANSMITTED DISEASES (STDS): THE FIRST-PART VOIDED URINE. Hoover Adger, Mary-Ann Shafer, Richard L. Sweet, Julius Schachter (Spon. by Melvin M. Grumbach), Univ. of California, Dept. of Ped., Ob-Gyn., and Lab. Med., San Francisco. (1)

3. ASSESSMENT OF TEENAGE PARENTING. Anne Willoughby, Fernando S. Mendoza, Paula M. Duke, Judith Williams, Ruth T. Gross, Stanford Univ. Med. Ctr., Dept. of Ped., Stanford. (25)

4. IMPACT OF TRANSCUTANEOUS OXYGEN MONITORING (TCOM) ON QUALITY AND COST OF NEONATAL INTENSIVE CARE. Keith J. Peevy and Michael W. Hall (Spon. by Edwin R. Highes), Univ. of South Alabama, Dept. of Ped. and Resp. Therapy, Mobile. (92)

5. EFFECTS OF CHRONIC HEALTH CONDITIONS ON SCHOOL ADAPTATION. Mary G. Fowler and Mary P.F. Johnson (Spon. by Frank Loda), Univ. of No. Carolina, Dept. of Ped., Chapel Hill. (48)

6. A STUDY OF CHILD SURVIVORS OF LEUKEMIA: ANXIETY, BEHAVIOR PROBLEMS, SELF ESTEEM, AND ACADEMIC ACHIEVEMENT. Louise M. Wulff (Spon. by Allen D. Schwartz), Univ. of Maryland Sch. of Nursing, Baltimore.(128)

7. PSYCHIATRIC DISORDER IN CHILDREN WITH PHYSICAL DISABILITIES. N. Breslau, Dept. of Epidem. \& Comm. H1th., Sch. of Med., Case Western Reserve Univ., Cleveland.

8. IMMUNITY OF YOUNG ADULTS TO CHILDHOOD DISEASES. Alan W. Lievens, Jean Taylor-Wiedeman, Philip A. Brune11, Dept. of Ped., U.T. H1th. Sci. Ctr., San Antonio. (537)

9. GROWTH DEFICIENCIES IN MEXICAN-AMERICAN CHILDREN IN THE UNITED STATES. Fernando S. Mendoza and Ricardo 0. Castillo (Spon. by Ruth T. Gross) Stanford Univ. Dept. of Ped. and Univ. of California, San Francisco, Dept. of Ped. (538)

10. ASEPTIC MENINGITIS IN JEFFERSON COUNTY, ALABAMA. Michael J. Barrett, Raymond A. Strikas, Martha F. Rogers, Charles Rabkin, W. James Alexander (Spon. by G.P. Oakley) Centers for Dis. Control, Atlanta.(508)

11. EPIDEMIC MEASLES IN CHICAGO IN 1983: SUSTAINED TRANSMISSION IN THE PRESCHOOL POPULATION. Michael L. Bennish, Paul M. Arnow, Sandra A. Doveikis, and Marc 0. Beem, Univ. of Chicago, Wyler Children's Hosp., Dept. of Ped. and Med., Chicago. (510) 
12. EFFICACY OF THE OVERGOWN IN PREVENTING NOSOCOMIAL INFECTION IN A PEDIATRIC INTENSIVE CARE UNIT. Leigh G. Donowitz (Spon. by J. Owen Hendley), Univ. of Virginia Sch. of Med., Dept. of Ped., Charlottesville. (517)

13. AGE OF DPT IMMUNIZATION OF SPECIAL CARE NURSERY (SCN) GRADUATES. Betty Vohr, William Oh, Brown Univ., Women \& Infants Hosp., Dept. of Ped., Providence. (554)

14. TIMING OF RE-EVALUATION FOR INITIAL FOLLOW-UP VISIT (FUV) FOR ACUTE OTITIS MEDIA WITH EFFUSION (AOME): RANDOMIZED COMPARATIVE STUDY OF IODAYS vs 30 DAYS. Richard H. Schwartz, Wm. J. Rodriguez and Kenneth M. Grundfast, Children's Hosp. Natl. Med. Ctr., George Washington Univ. Sch. of Med., Washington. (822)

15. USE OF DISH SOAP AS AN EMETIC IN THE OUTPATIENT MANAGEMENT OF ACCIDENTAL POISONINGS. George C. Rodgers, Jr., Patience Fort (Spon. by Billy F. Andrews), Univ. of Louisville Sch. of Med., Dept. of Ped. and the Kentucky Regional Poison Ctr. of Kosair-Children's Hosp., Louisville. (818)

16. AN ANALYSIS OF OFFICE BACTERIOLOGY AS PERFORMED BY PEDIATRICIANS IN PRIVATE PRACTICE. H.J. Hamrick and R.J. Schwartz, Dept. of Ped., Univ. of North Carolina, Sch. of Med., Chapel Hill.

17. ANEMIA IN INFANTS WITH MILD INFECTIONS. Jərry D. Reeves, Ray Yip, Peter R. Dallman, David Grant Med. Ctr., Travis AFB, and Univ. of California, San Francisco, Sch. of Med., Dept. of Ped., San Francisco. (816)

18. EFFICACY OF ENZYME IMMUNOASSAY (EIA) FOR DETECTION OF CHLAMYDIA TRACHOMATIS (CT) INFECTION. M.L. Kumar, T. Anglin, R. Paul, D. Krowchuk, R. Brown, N. Wimpie, C. Leman (Spon. by K. King), Cleveland Metro. Gen. Hosp. Dept. of Ped., Cleveland, and Abbott Diagnostics, N. Chicago. (1103)

19. MOBILIZATION OF TYPE b CAPSULE GENE(S) IN HAEMOPHILUS INFLUENZAE b (Hib) BY CELL TO CELL CONTACT. P.M. Mendelman, V.Ph. Syriopoulou, S.L. Gandy, C.A. Doroshow, J.I. Ward, A.L. Smith, Univ. of Washington Children's Hosp., Dept. of Ped., Seattle. (1113)

20. ROLE OF INTRAVASCULAR REPLICATION IN THE PATHOGENESIS OF EXPERIMENTAL HAEMOPHILUS INFLUENZAE B (Hib) BACTEREMIA. Lorry G. Rubin, Andre Zwahlen, E. Richard Moxon, SUNY at Stony Brook \& Children's Hosp. of Long Island Jewish-Hillside Med. Ctr., Dept. of Med., New Hyde Park, and Johns Hopkins Univ., Dept. of Ped., Baltimore. (1135)

21. INFECTION OF HUMAN MONONUCLEAR LEUKOCYTES WITH RESPIRATORY VIRUSES. L.R. Krilov, R.M. Hendry and K. McIntosh, Children's Hosp., Div. of Inf. Dis., Boston. (1102)

22. MOLECULAR EPIDEMIOLOGY OF CYTOMEGALOVIRUS (CMV) IN DAY CARE CENTERS (DCC). Cecelia Hutto and Robert F. Pass, Univ. of Alabama in Birmingham, Dept. of Ped., Birmingham. (1091) 
23. THE USE OF HOMOLOGOUS AND HETEROLOGOUS ROTAVIRUS ANTIBODIES FOR THE PREVENTION OF ROTAVIRUS GASTROENTERITIS. Genevieve A. Losonsky, Joseph Eiden, Steve Vonderfecht, Robert Yolken, Dept. of Ped. and Comparative Med., Johns Hopkins Sch. of Med., Baltimore. (1107)

24. SIMULTANEOUS ADMINISTRATION OF TWO LIVE INFLUENZA VACCINES. P.F. Wright, M. Bhargava, J. Thompson, D.T. Karzon, Vanderbilt Univ., Nashville. (1158)

25. STAPHYLOCOCCAL EPIDERMIDIS SLIME EFFECTS ON BACTERIAL OPSONIZATION AND PMN LEUKOCYTE FUNCTION. W. Regelmann, Ernie D. Gray, Priscilla Thomas, and George Peters, Univ. of Minnesota, Dept. of Ped., Minneapolis, and Hygiene Inst., Univ. of Cologne, West Germany. (1131)

26. EFFICACY OF VARIOUS MONOCLONAL ANTIBODIES (Ab) AGAINST E. COLI (EC). Kwang Sik Kim, Daisy Green, Alan Cross, Bennett Kaufman, Wende11 Zollinger, Jerold Sacoff and Michael Apicella (Spon. by B.F. Anthony), Harbor-UCLA Med. Ctr., Dept. of Ped., Torrance, Walter Reed Army Med. Ctr., Washington, SUNY at Buffalo, Dept. of Med., Buffalo. (1100)

27. ALTERED HELPER: SUPPRESSOR LYMPHOCYTE RATIO DURING CYTOMEGALOVIRUS INFECTION OF MICE. Matthew S. Sell, James F. Bale, Jr., and Roger Giller (Spon. by Ronald G. Strauss), Univ. of Iowa Coll. of Med., Dept. of Ped., Iowa City. (1138)

28. COMPARISON OF NATIVE AND REDUCED AND ALKYLATED HUMAN IV IMMUNE SERUM GLOBULIN (ISG) IN EXPERIMENTAL H. INFLUENZAE TYPE B INFECTION. J. Schreiber, V. Barrus and G. Siber (Spon. K. McIntosh), Children's Hosp. and Dana-Farber Cancer Inst., Dept. of Inf. Dis., Boston. (1137)

29. A PROSPECTIVE SEROEPIDEMTOLOGICAL SURVEY OF HERPES SIMPLEX (HSV) INFECTIONS IN A COLLEGE POPULATION. E. Wu, J. Sayre, E. Wiesmeier, D. Bernstein, B. Visscher, Y. Bryson, Univ. of California, Sch. of Med., Los Angeles. (1159)

30. ANTIBODY DECLINE IN SPLENECTOMIZED CHILDREN AFTER PNEUMOCOCCAL VACCINATION. G. Scott Giebink, Chap T. Le, and Gerald Schiffman, Univ. of Minnesota, Dept. of Ped. and Biometry, Minneapolis, and Downstate Med. Ctr., Dept. of Microbiol., Brooklyn. (1076)

31. MUROLYTOGRAPHY: A NEW PEPTIDOGLYCAN ANALYSIS TECHNIQUE FOR S. AUREUS EPIDEMIOLOGY. Asher Barzilai, Alexander C. Hyatt and David S. Hodes, The Mt. Sinai Sch. of Med., Dept. of Ped., New York. (1041)

32. CYTOMEGALOVIRUS (CMV) INFECTIONS: INFANT DEVELOPMENT VS. DAY CARE CENTERS. Linda A. Jones, Paula M. Duke, Anne S. Yeager, Stanford Univ. Sch. of Med., Dept. of Ped., Stanford. (1097)

33. POLYACRYLAMIDE GEL ELECTROPHORESIS (PAGE) OF ROTAVIRUS RNA AFTER SERIAL PASSAGE AND IN CHRONIC INFECTION. Joseph Eiden, Genevieve Losonsky, Steve Vonderfecht, John Johnson, Robert Yolken, Johns Hopkins Med. Sch., Baltimore. (1065) 
34. GONADAL DYSGENESIS AND GONADOBLASTOMA IN CRYPTOPHTHALMOS SYNDROME. Frank Greenberg, Bruce Keenan, Viamny De Yanis and Milton J. Finegold (Spon. by Arthur L. Beaudet), Baylor Coll. of Med., Dept. of Ped. and Path., Houston. (1259)

35. CAVUM VERGAE AND NEUROLOGIC ABNORMALITIES. Marvin E. Miller, Frederick Horner, and Daniel Kido (Spon. by Elizabeth R. McAnarney), Univ. of Rochester Sch. of Med. and Dentistry, Dept. of Ped. and Radiol., Rochester. (1266)

36. H-Y ANTIGEN DETECTED BY ENZYME LINKED IMMUNOSORBENT ASSAY (ELISA). A. Simpson, P. Saenger, S. Pang, C.A. Moreira-Filho, M. Brunner, S.S. Wachtel, Dept. of Ped., A. Einstein Coll. Med., Bronx and Cornell Univ. Med. Ctr., New York. (1273)

37. HIGH RATE OF MORPHOLOGICAL TRANSITION IN CHILDREN WITH STEROID SENSITIVE MINIMAL CHANGE NEPHROTIC SYNDROME (MCNS). Kishore Phadke, Orlando Adamson, Anthony Nicastri, Howard Trachtman, Amir Tejani, SUNY, DMC, Renal Div., Dept. of Ped. and Path., Brooklyn. (1656)

38. SODIUM BENZOATE (BZ) ARRESTS PROGRESSION OF RENAL FAILURE IN INFANTILE PRIMARY OXALURIA (OXU). Barbara A. Fivush, Robert H. McLean, and Saul W. Brusilow, Children's Hosp., Washington and Johns Hopkins Univ., Dept. of Ped., Baltimore. (1572)

39. C3NEF PRODUCTION BY PERIPHERAL BLOOD LYMPHOCYTES (PBL) FROM NORMAL INDIVIDUALS AND PATIENTS WITH MEMBRANO-PROLIFERATIVE GLOMERULONEPHRITIS (MPGN), Roger E. Spitzer and Ann E. Stitzel, SUNY Upstate Med. Ctr., Dept. of Ped., Syracuse. (1650)

40. HEMODYNAMIC EFFECTS OF CHRONIC PARTIAL URETERAL OBSTRUCTION (CPUO) IN THE NEWBORN GUINEA PIG. Robert L. Chevalier and Anthony V. Broccoli (Spon. by Alan D. Rogol), Univ. of Virginia Med. Ctr., Dept. of Ped., Charlottesville. (1579)

41. PHOSPHATE (Pi) UPTAKE IN FETAL LAMB (FL) RENAL BRUSH BORDER MEMBRANES (BBMV). Lawrence Rufer, Eddie S. Moore, Christine S. Mooers, and Nochik Park, Dept. of Ped., Michael Reese Hosp. \& Med. Ctr., Dept. of Biol. Sci., Univ. of Illinois at Chicago Grad. Sch., Chicago. (1620)

42. INCREASED RENAL BLOOD FLOW (RBF) AFTER TRANSIENT RENAL ISCHEMIA. MarC C. Browning (Spon. by William B. Lorentz), Bowman Gray Sch. of Med., Dept. of Ped., Winston-Salem. (1571)

43. DOPAMINE RECEPTORS (DR) IN DOG INTRARENAL ARTERIES (IRA). Robin A. Felder, John J. Worthington, and Pedro A. Jose, Dept. of Ped., Georgetown Univ. Med. Ctr., Washington. (1589)

44. CONTRIBUTION OF THE FETAL KIDNEY TO PRESERVATION OF FLUID VOLUME DURING HYPOVOLEMIA. Salha S. Daniel, Raymond I. Stark, Pamela J. Tropper and L. Stanley James, Columbia Univ., Coll. of Phys. \& Surg., Babies Hosp. Div. Perin., Dept. of Ped. \& Anest., New York. (1587) 
45. HYPERCALCIURIA: AN IMPORTANT CAUSE OF HEMATURIA IN CHILDREN. Fielding B. Stapleton, Shane Roy, III, Horace N. Noe, and Gerald Jerkins, Dept. of Ped. and Urol., Univ. of Tennessee Ctr. H1th. Sci., and LeBonheur Children's Med. Ctr., Memphis. (1651)

46. PREDICTIVE FACTORS AFFECTING FIRST PEDIATRIC CADAVERIC TRANSPLANT SURVIVAL. Bruce Z. Morgenstern, H. Jorce Baluarte, Eugene L. Sobe1, Bruce A. Kaiser, Martin S. Polinsky, Sharon A. Perlman, Alan B. Gruskin, St. Christopher's Hosp. for Children, Dept. of Ped., Temple Univ. Sch. of Med., Philadelphia. (1623)

47. RENAL TUBULAR ACIDOSIS TYPE 4 IN NEONATAL UNILATERAL KIDNEY DISEASES. Uri Alon, Michael B. Kodroff, Bruce H. Broecker, Barry V. Kirkpatrick, and James C.M. Chan, Med. Co11. of Virginia, Richmond. (1574)

48. PULSE METHYLPREDNISOLONE (MP) THERAPY OF NEPHROTI SYNDROME WITH FOCAL GLOMERULOSCLEROSIS (FGS). Vivia M. Reznik, Bruce M. Tune, William R. Griswold, Martha Vasquez, and Stanley A. Mendoza, UCSD Sch. of Med. and Stanford Univ. Sch. of Med., Dept. of Ped., La Jolla and Stanford, and Dept. of Path., VA Hosp., La Jolla. (1632)

49. ALDOSTERONE--A POTENT STIMULATOR OF THE RENAL KALLIKREIN-KININ SYSTEM DURING FETAL LIFE. Jean E. Robillard, Kenneth T. Nakamura, Oliva McWeeny, Sindy Wear and William Lawton, Univ. of Iowa, Dept. of Ped. and Med., Iowa City. (1633)

50. EFFECTS OF UNILATERAL HEMISPHERE LESIONS ON LANGUAGE AND INTELLECTUAL DEVELOPMENT. Dorothy M. Aram (Spon. by R.J. Martin) CWRU Dept. of Ped., Cleveland. (1666)

51. NEUROBEHAVIORAL DEFICITS IN MODERATELY JAUNDICED TERM INFANTS. J. Tyson, F. Eubanks, T. Shimatsu, R.E. Lasky, A. Rupert, M. Porter (Spon. by C. R. Rosenfeld) Southwestern Med. Sch., Dept. of Ped., and Univ. at Dallas, Dept. of Comm. Disorders, Dallas. (1725)

52. CEREBELLAR HEMORRHAGE: DEVELOPMENTAL \& NEUROLOGIC OUTCOME. W. Danie1 Williamson, Alan K. Percy, Marvin A. Fishman, William R. Cheek, Susan D. Thurber, Murdina M. Desmond, Baylor Coll. of Med., Texas Children's Hosp., Dept. of Ped., Houston. (1728)

53. SAFETY OF A HIGHER LOADING DOSE OF PHENOBARBITAL IN THE TERM NEWBORN. S.M. Donn, T.H. Grasela, G.W. Goldstein, Dept. of Ped., Neurol., Pharm., and Coll. of Pharm., Univ. of Michigan, Ann Arbor. (1673)

54. HEMORRHAGIC AND ISCHEMIC LESIONS IN THE PRETERM BRAIN. Yehoshua Zarfin, Karen Pape, Chukwuma Nwaesei, David Martin, Alan Daneman, Wendy Murphy (Spon. by P.M. Fitzhardinge), Res. Inst., Hosp. for Sick Children, Dept. of Ped. and Radiol., Univ. of Toronto. (1710)

55. CSF LACTATE DEHYDROGENASE PREDICTS SEVERE NEONATAL INTRAVENTRICULAR HEMORRHAGE. Stephen Engelke, John Wimmer, Rita Saldanha, Grant Somes and Arthur Kopelman (Spon. by Jean Kenny), East Carolina Univ. Sch. of Med., Dept. of Ped., Greenville. (1677) 
56. VALIDATION OF THE PULSED DOPPLER TECHNIQUE FOR ASSESSMENT OF CEREBRAL BLOOD FLOW VELOCITY. Bo P.W. Lunde11, Daniel P. Lindstrom, Thomas G. Arnold, Kathleen A. Kennedy, Hakan Sunde11, Vanderbilt Univ. Sch. of Med., Dept. of Ped., Nashville. (1699)

57. REGIONAL CEREBRAL BLOOD FLOW (CBF) IN A RAT MODEL PARALLELS CHANGES IN HUMAN PERINATAL HYPOXICISCHEMIC ENCEPHALOPATHY (HIE). F. Silverstein, K. Hassett, and M. Johnston (Spon. by Gary Goldstein), Univ. of Michigan, Dept. of Ped. Neuro., Ann Arbor. (1686)

58. SYMPATHETIC NERVE STIMULATION ATTENUATE CEREBRAL BLOOD FLOW (CBF) IN HYPERCAPNIC NEWBORN PIGLETS. L. Craig Wagerle, Savitri P. Kumar, and Maria Delivoria-Papadopoulos, Univ. of Pennsylvania, Dept. of Physiol. and Ped., Philadelphia. (1726)

59. CERVICAL CORD COMPRESSION IN ACHONDROPLASIA. C. Reid, H. Wang, R. McPherson, B. Maria, C. Francomano, J. Phillips, III, A. Rosenbaum and R. Pyeritz, Johns Hopkins Univ. Sch. of Med., Dept. of Ped., Radiol., Anesth. and Neuro., Baltimore. (1715)

60. SYSTEMIC HYPERTENSION ASSOCIATED WITH POOR OUTCOME AFTER ACUTE BRAIN INJURY. Robert K. Kanter, James B. Carrol1, Ernest M. Post (Spon. by Roger E. Spitzer), SUNY, Upstate Med. Ctr., Dept. of Ped., Syracuse. (1689)

\section{POSTER SESSION III}

Thursday, May 3, 1984, 7:30 AM West Lounge/Garden Lane/Embarcadero

1. LEVEL, TREND AND VARIABILITY OF BLOOD PRESSURE DURING CHILDHOOD: THE MUSCATINE STUDY. Ronald M. Lauer, William R. Clarke, Univ. of Iowa, Dept. of Ped. and Prevent. Med., Iowa City. (184)

2. SYSTEMIC AND PULMONARY VASCULAR EFFECTS OF DOBUTAMIN IN NEWBORN LAMBS. Becky Williams, James E. Fewell, and Donald E. Hill, Univ. of Arkansas for Med. Sci., Dept. of Ped., Little Rock. (218)

3. NON-INVASIVE DETECTION OF CARDIAC SPECIALIZED CONDUCTION SYSTEM POTENTIALS IN PEDIATRIC PATIENTS. Ehud Krongrad, M.D., Nan-Koong Wang, M.D., Yoram Lass, M.D., Coll. of Physicians \& Surg., Columbia Univ., New York, and Sackler Sch. of Med., Tel Aviv. (173)

4. LONG-TERM RESULTS OF BALLOON VALVULOPLASTY OF THE PULMONARY VALVE. D. Kveselis, A.P. Rocchini, A. Rosenthal, Univ. of Michigan. (176)

5. DOPAMINE(DA) INFUSION: EFFECTS ON HEMODYNAMIC AND CATECHOLAMTNE (CA) CONCENTRATIONS. Arno L. Zaritsky, Murray M. Pollack, Deborah H. Schaible, C. Raymond Lake (Spon. by G. Rosenquist), George Washington Univ. Sch. of Med., Children's Hosp. Nat1. Med. Ctr., Dept. of Ped., Anesth., Washington. (228) 